\title{
ІДЕНТИФІКАЦЙНІ ДАНІ: ПРАВОВІ МЕХАНІЗМИ РОЗРОБКИ КЛАСИФІКАТОРІВ
}

\begin{abstract}
Костенко О. В., доктор філософії (Ph.D.) в галузі права, в.о. завідувача науково-дослідної лабораторії теорії і права иифрових трансформацій науково-дослідного иентру цииррових трансформацій і права НДІ інформатики і права Наиіональної академії правових наук України, м. Київ, Украӥна, ORCID ID: https://orcid.org/0000-0002-2131-0281
\end{abstract}

DOI: https://doi.org/10.31435/rsglobal_conf/25022021/7418

\begin{abstract}
Modern society has entered into a full-scale implementation of the scientific and technological revolution 4.0 and economic globalization. One of the driving forces of the new scientific and technological revolution is the development of information and communication technologies and the introduction of technologies for the transmission and use of information. Today, the problem of legal support for the management of the confidentiality of data used to identify subjects and objects by their unique attributes is relevant. The degree of solving the problem of managing the processes of digital identification data is one of the main factors in the modern development of crossborder e-economy and trade.

There is a situation when in Ukraine in all spheres of public life modern information and communication technologies are rapidly introduced in the actual absence of legal institutions for the management of identification and personal data, biometrics, IoT devices and artificial intelligence.

A significant complication for the development and operation of identification data management systems is the lack of a single strategy in this area, socio-legal model of public relations, a single classifier of identification data and a single scheme of identification of subjects by identification data, mechanisms for legal rights and responsibilities. projects, legal procedures for biometric identification, methods of identification of IoT devices and artificial intelligence.

Keywords. Identification data management, personal data, identification data classifier, identification attributes, identification systems.
\end{abstract}

Вступ. Сучасне суспільство увійшло в епоху новітньої науково-технічної революції та економічної глобалізації. Розвиток глобального інформаційного суспільства і вдосконалення інформаційно-комунікаційних технологій підвищують швидкість і обсяги обміну даними, але одночасно підвищують ризики їх незаконного розповсюдження шляхом несанкціонованого доступу до інформаційних систем. На сьогодні однією із рушійних сил нової науковотехнічної революції $є$ розвиток інформаційно-комунікаційних технологій і впровадження технологій передачі та використання інформації.

Одним із цінних ресурсів є персональні дані. Особлива увага приділяється збереженню інформації персонального характеру [1], а саме ідентифікаційним даним, тобто тим даним, що застосовуються в процесах ідентифікації. Одним із ключових елементів технологій передачі інформації є дані за якими можливо ідентифікувати суб'єктів та об'єктів за притаманні їм ідентифікаційні атрибути, тобто здійснювати процеси управління ідентифікаційними даними.

Мета дослідження. Вирішення актуального завдання забезпечення правового захисту, визначення правових засад, правових механізмів та управління ідентифікаційними даних як для правової доктрини, так і для законодавства в цілому.

Методи дослідження. Питання правового регулювання суспільних відносин, пов'язаних 3 використанням персональних даних та їх виду ідентифікаційних даних для пристроїв Інтернет речей, систем управління інформаційною безпекою (СУІБ), штучного інтелекту, електронних довірчих послуг, квантової криптографії, досліджували українські вчені: О. Баранов, В. Брижко, I. Горбенко, Д. Дзюба, В. Пилипчук О. Перевозчикова， О. Потій， О. Різник， М. Крачевський, О. Радутний, М. Коваль., І. Горбенко. За останні роки питання створення механізмів управління ідентифікаційними даними в правовому аспекті не висвітлювалась.

Зауважимо, що як вітчизняна так і зарубіжна правова наукова думка переважно зосереджена на проблематиці безпекового забезпечення окремих видів ідентифікаційних даних. 
Також звертає увагу на себе недостатність теоретичних напрацювань на тему, що досліджується, а також відсутність комплексних досліджень в цьому напрямку.

Результати дослідження. Вирішення проблеми управління процесами застосування цифрових ідентифікаційних даних є основою для сучасного розвитку електронної економіки та торгівлі. Нині багато міжурядових груп, держав, приватних міжнародних груп і комерційних структур активно вивчають питання управління ідентифікаційними даними і наявні в цій галузі можливості, розробляють технічні стандарти і процедури, а також ведуть пошук шляхів вирішення правового забезпечення реалізації життєздатних систем ідентифікації [2].

Ідентифікаційними даними вважається інформація про конкретного суб`єкта в формі одного або декількох атрибутів, що дозволяють суб'єкту бути в достатній мірі відмінним в певному контексті або набір атрибутів особи, які дозволяють цій особі відрізнятися від інших осіб у конкретному контексті. [3].

Управлінням ідентифікаційними даними в широкому сенсі прийнято вважати набір прийомів, що дозволяють управляти процесами ідентифікації, аутентифікації і авторизації фізичних і юридичних осіб, пристроїв та інших суб'єктів в режимі онлайн з метою отримання електронних сервісів та даних.

Україною зроблено певні зусилля в напрямку технічної організації та розвитку процесів електронної ідентифікації, які спрямовані на виключно технічні способи ідентифікації. Наразі пропонується схема побудови технологічного транскодеру між різноманітними системами ідентифікації, що створює низку суттєвих правових ризиків та правових невизначеностей і не сприяє зростанню довіри до державних цифрових сервісів, інформаційних ресурсів та технологій.

Суттєвим ускладненням для функціонування систем управління ідентифікаційними даними стала відсутність єдиного класифікатора ідентифікаційних даних. Невизначеності також додає і низка різних схем ідентифікації суб'єктів за ідентифікаційними даними та їх правовий статус.

Розбудова національної Інтегрованої системи електронної ідентифікації за методом декодера або шлюзу між різноманітними інформаційними ресурсами та системами ідентифікаційних даних, на нашу думку, є морально застарілим, малоефективним рішенням та містить багато ризиків, перш за все юридичних.

3 огляду на глобальний характер проблеми управління ідентифікаційними даними, вирішувати іiі необхідно із урахуванням міжнародного досвіду та рекомендацій ЮНСИТРАЛ в рамках міждержавного співробітництва.

В даний час законодавча база, яка регулює суспільні відносин в сфері персональних даних знаходиться на стадії початкового розвитку. Національне законодавство безперервно модернізується та поповнюється новими нормативно-правовими актами та дефініціями, що водночас призводить до термінологічного розбалансування в сфері інформаційних технологій. Незважаючи на це, зусилля в правовому регулюванні застосування персональних даних, нормотворча база в тому числі і в сфері управління ідентифікаційними даними відстає від реальних потреб суспільства і держави, залишаючись серйозною проблемою інформаційного права. Законодавча база в повній мірі не відображає реальний стан реагування держави на правопорушення із використанням ідентифікаційних та персональних даних, а вкрай мінімізовані заходи державно-правового примусу навпаки підштовхують до вчинення протиправних дій.

Враховуючи істотне відставання України від ряду держав та Європейського союзу найближчим завданням правого регулювання сфери персональних та ідентифікаційних даних є: формування та розвиток законодавчої основи із урахуванням сучасних світових практик в сфері ідентифікаційних та персональних даних; модернізація інституційної структури дісвого нагляду за дотримання прав в сфері персональних даних; створення правової інституційної структури управління ідентифікаційними даними.

Фактично необхідно створити нову технічну систему та відповідний правовий інститут управління ідентифікаційними даними. Завдання технічної системи надати фізичним особам можливість надійно взаємодіяти 3 багатьма підсистемами та технічними пристроями за допомогою сучасних технологічних рішень на основі штучного інтелекту, комплексу сучасних технічних стандартів, юридичних правил та норм, порядків i процедур перевірки ідентифікаційних даних з метою забезпечення тотожності ідентифікаційних даних з фізичною або юридичною особою, пристроєм або цифровим об'єктом ведення транзакцій, а також зберігання і захисту ідентифікаційних даних. 
Завдання правової інституційної структури - забезпечити функціонування сучасної нормативно-правової бази регулювання суспільних відносин у сфері управління ідентифікаційними даними, яка визначить перш за все порядок транскордонного управління ідентифікаційними даними, права та обов'язки суб'єктів та об'єктів (систем із використання засобів штучного інтелекту), види протиправних суспільно небезпечних діянь та юридичну відповідальність за їх скоєння, передбачить порядок страхування транзакцій, забезпечить виконання зобов'язань сторін та відшкодування завданої шкоди тощо.

Ключовим сегментом технічної і правової структури є ідентифікаційні дані. На нашу думку роботу із формування нормативно-правових актів в сфері управління ідентифікаційними даними слід розпочати із розробки глосарію термінів та понять, а також класифікатора ідентифікаційних даних [4].

Для формування класифікатора ідентифікаційних даних доцільно застосувати метод кольорового маркування рівнів даних, прийнятого в світі для визначення ступеню важливості та критичності ситуації.

Так до «червоного рівня» необхідно віднести всі види біометричних ідентифікаційних даних, як стійкі та статичні відомості, необхідні для ідентифікації суб'єкта, на підставі його фізіологічних або біологічних параметрів. Також до цього рівня будуть відноситись ідентифікаційні дані пристроїв ІоТ, системи штучного інтелекту та роботи андроїди класу IIIASI (супер ШI), які застосовуються в медицині, військовій сфері, на об’єктах критичної інфраструктури [5].

До «помаранчевого рівня» доцільно віднести ідентифікаційні дані що містяться на фізичних носіях (паспорт; ID-паспорт, військовий квиток, посвідчення водія, номер свідоцтва про загальнообов'язкове соціальне страхування, індивідуальний номера платника податків, інші ідентифікаційні дані, надані особі державними органами) [6].

«Жовтим кольором» бажано маркувати ідентифікаційні дані що містяться в банківських та соціальних картах, номери мобільних телефонів, особисті паролі і інші електронні ідентифікатори.

Відповідно до ідентифікаційних даних «зеленого кольору» можливо віднести загальнодоступні дані які містяться у відкритих джерелах, соціальних мережах, засобах масової інформації тощо.

Висновки. Такий підхід до класифікації ідентифікаційних даних дозволить не тільки розпочати структуроване створення нормативно-правових актів в даній сфері, але й спрямувати необхідні юридичні та технічні заходи на розробку систем кібернетичної безпеки із захистом ідентифікаційних даних за рівнями цінності охоронюваних інформаційних ресурсів тобто червоним / помаранчевим / жовтим / зеленим.

Класифікація ідентифікаційних даних сприятиме розробки сучасних процедур, що дозволить управляти процесами ідентифікації, автентифікації i авторизації фізичних i юридичних осіб, пристроїв ІоТ в режимі онлайн, а також процедурами інформаційної безпеки та захисту ідентифікаційних даних.

\section{ЛITEРАТУРА}

1. Бем М. В., Городиський І. М., Саттон Г., Родіоненко О. М. Захист персональних даних: Правове регулювання та практичні аспекти: науково-практичний посібник. - К.: К.І.С., 2015.

2. Обзор вопросов управления идентификационными данными [Електронний ресурс] // Комиссия Организации Объединенных Наций по праву международной торговки Рабочая группа IV (Электронная торговля). - 2014. - Retrieved from A/CN.9/WG.IV/WP.120 https://undocs.org/ru/A/CN.9/WG.IV/WP.120.

3. Костенко О.В. Ідентифікація IоТ: витоки проблеми правового регулювання управління ідентифікаційними даними / О.В. Костенко// Фаховий науковий журнал «Јuris Europensis Scientia». 2021. - № 1.

4. Правовые вопросы, связанные с управлением идентификационными данными и удостоверительными услугами Термины и понятия, имеющие отношение к управлению идентификационными данными и удостоверительным услугам. Retrieved from https://undocs.org/ru/A/CN.9/WG.IV/WP.150.

5. Helena Machado, Susana Costa. Biolegality, the Forensic Imaginary and Criminal Investigation. Revista Crítica de Ciências Sociais, Annual Review. Retrieved from https://journals.openedition.org/rccsar/490.

6. Руководство ОЭСР по электронному удостоверению подлинности (2007 год). Retrieved from http://www.oecd.org/dataoecd/32/45/38921342.pdf. 